\title{
Pola Tabligh Organisasi Jamiyah Nurul Iman Bandung
}

\section{Yoga Hadi Permana \& Zainal Abidin}

Jurusan Komunikasi dan Penyiaran Islam, Fakultas Dakwah dan Komunikasi, UIN

Sunan Gunung Djati, Bandung

*Email: yogahadipermana03@gmail.com

\begin{abstract}
ABSTRAK
Tujuan tulisan ini untuk mengetahui pola tabligh yang diterapkan oleh organisasi jamiyah Nurul Iman Kota Bandung melalui unsur-unsur yang terkandung dalam kegiatan-kegiatan keagamaan. Penelitian ini menggunakan metode analisis deskriptif dengan pendekatan kualitatif, Data diperoleh melalui observasi dan wawancara dengan pihak terkait, seperti ketua, sekretaris, mubaligh, serta anggota dalam organisasi jamiyah Nurul Iman Kota Bandung, dan ditunjang oleh tinjauan pustaka. Hasil penelitian menunjukkan bahwa pola tabligh dalam organisasi Jamiyah Nurul Iman Bandung dapat dilihat dari kegiatan, pola materi, pola metode serta pola komunikasi yang terjadi dalam aktivitas tabligh organisasi jamiyah Nurul Iman Kota Bandung. Peneliti menemukan bahwa, komunikasi dalam kegiatan tabligh lebih banyak mengajak serta mempengaruhi jama'ah untuk merealisasikan pesan-pesan keislaman yang disampaikan mubaligh melalui tindakan-tindakan yang dilakukan mubaligh serta didukung oleh kegiatan-kegiatan tabligh dalam organisasi Jamiyah Nurul Iman.
\end{abstract}

Kata Kunci : Pola, Tabligh, Komunikasi, Organisasi.

\section{ABSTRACT}

The purpose of this paper is to know the tabligh pattern applied by the Islamic Nurul Iman Bandung with elements contained in it's religious activities. This research uses descriptive analysis method with qualitative approach. The data collected by observation and interview with related parties, such as chairman, secretary, preacher, and member in jamiyah organization Nurul Iman Bandung, and supported by literature review. The results showed that the pattern of tabligh in the organization Jamiyah Nurul Iman Bandung can be seen from the activities, material patterns, patterns of methods and 


\section{Y. H. Permana \& Z. Abidin}

communication patterns that occur in the activities tabligh Jamiyah Nurul Iman Bandung. Researchers found that communication in the activities of tabligh more invites and influences jama' ah to realize the messages of Islam submitted preachers through the actions of preachers and supported by activities tabligh within the organization Jamiyah Nurul Iman.

Keywords: Pattern, Tabligh, Communication, Organization.

\section{PENDAHULUAN}

Banyak kegiatan tabligh di setiap kalangan masyarakat kecil dan marjinal, misalnya di kalangan pengemis, anak jalanan, bahkan pengajian di kalangan waria. Termasuk juga di kalangan pedagang kecil yaitu pedagang kali lima. Di Bandung, pedagang kali lima sangat banyak, namun sedikit dari kalangan pedagang kali lima yang memiliki keinginan untuk membentuk atau mengadakan perkumpulan keagamaan.

Kegiatan tabligh tidak hanya dilakukan dalam sebuah kalangan masyarakat pedesaan yang mayoritas penduduknya masih kental dengan tradisi keagamaan. Banyak juga di daerah perkotaan yang mayoritas masyarakatnya bukan penduduk asli kota tersebut namun tetap ada yang membentuk suatu perkumpulan keagamaan. Bahkan profesi atau pekerjaan tidak menjadi hambatan untuk membentuk suatu perkumpulan keagamaan.

Banyak komunitas, kelompok atau organisasi tabligh yang terselenggara di Indonesia khususnya di Bandung. Selama kegiatan tersebut hanya mengharapkan ridha Allah SWT maka tujuan tabligh akan sangat dirasakan bagi masyarakat di sekitarnya. Tidak ada batas kalangan dalam melaksanakan kegiatan tabligh. Mulai dari kalangan bawah, menengah, hingga kalangan atas. Baik itu dari kalangan pejabat, kalangan polisi, kalangan pemuda, komunitas motor, sampai kalangan pedagang.

Salah satu komunitas atau organisasi pengajian yang diselenggarakan oleh para pedagang adalah organisasi jamiyah Nurul Iman. Walaupun organisasi ini dari kalangan pedagang, namun ada beberapa anggota atau pengurus yang berprofesi bukan sebagai pedagang. Organisasi jamiyah Nurul Iman terbentuk sejak tahun 2001. Sekretariat organisasi ini terletak di Cibaduyut No. 171 RT 04 RW 06 Kecamatan Bojongloa Kidul Kelurahan Kebun Lega Kota Bandung. Anggota organisasi jamiyah Nurul Iman terdiri dari berbagai daerah dan berbagai jenis profesi, namun mayoritas anggotanya adalah orang Jawa Tengah dan berprofesi sebagai 
pedagang, mulai dari pedagang pecel lele, nasi goreng, warteg, pedagang di pasar tradisional, sampai pegawai pajak. Sejak awal berdiri sampai sekarang, organisasi jamiyah Nurul Iman selalu rutin melaksanakan kegiatan-kegiatan keagamaan, hal ini dikarenakan semangat anggota yang tinggi dalam melaksanakan kegiatan keagamaan.

Menurut data pengamatan peneliti terhadap jama'ah yang mengikuti kegiatan tabligh di organisasi jamiyah Nurul Iman, banyak manfaat yang dirasakan dalam pengajian tersebut. Bahkan peneliti melihat data keanggotaan organisasi jamiyah Nurul Iman semakin bertambah seiring berjalannya waktu. Dengan adanya hal tersebut menunjukkan bahwa dalam kegiatan tabligh organisasi jamiyah Nurul Iman memiliki dampak yang posotif bagi anggotanya.

Melihat adanya fenomena tersebut, peneliti bermaksud meneliti lebih dalam mengenai "Pola Tabligh Organisasi Jamiyah Nurul Iman Kota Bandung (Penelitian di Cibaduyut No. 171 RT 04 RW 06 Kecamatan Bojongloa Kidul Kelurahan Kebun Lega Kota Bandung)"

Adapun pertanyaan penelitian yang menjadi fokus penelitian dalam penelitian ini yaitu: Bagaimana program kegiatan di organisasi jamiyah Nurul Iman Kota Bandung?, Bagaimana pola materi tabligh pada organisasi jamiyah Nurul Iman Kota Bandung?, Bagaimana pola metode tabligh pada jamiyah Nurul Iman Kota Bandung?, Bagaimana pola komunikasi antara da’i dan jamaah pada jamiyah Nurul Iman Kota Bandung?

Seorang muslim harus memahami bahwa dirinya adalah subjek dakwah, ia adalah pelaku yang tidak boleh absen. Tidak ada pengecualian untuk bisa lepas dari kedudukannya tersebut dalam keadaan dan kondisi apapun baik secara lisan, tulisan ataupun perbuatan untuk meyebarkan ajaran dan nilai-nilai keislaman. Penyebaran Islam sebagai usaha untuk merealisasikan nilai-nilai ajaran-Nya di tengah-tengah kehidupan manusia, merupakan usaha dakwah yang harus dilakukan oleh segenap umat Islam. Kewajiban melakukan aktivitas tabligh ini merupakan karakter agama Islam sampai akhir zaman. Islam adalah agama dakwah, artinya agama yang selalu mendorong pemeluknya untuk senantiasa aktif melakukan kegiatan dakwah. Maju mundurnya umat Islam sangat bergantung dan berkaitan erat dengan kegiatan dakwah yang dilakukannya, karena itu Al-Qur'an dalam menyebut kegiatan dakwah dengan Ahsanu Qaul. Dengan kata lain, dakwah menempati posisi yang tinggi dan mulia dalam kemajuan agama Islam. 


\section{Y. H. Permana \& Z. Abidin}

Dalam perkembangan ilmu dakwah, tabligh diartikan lebih spesifik dan menjadi salah satu bentuk dakwah di antara bentuk-bentuk dakwah lain yang secara keilmuan dapat dibedakan walaupun dalam tataran praktis merupakan suatu satu kesatuan. Tabligh merupakan bentuk dakwah dengan cara menyampaikan atau menyebarluaskan (transmisi) ajaran Islam melalui media mimbar atau media massa dengan sasaran orang banyak. Tabligh pada prinsipnya bersifat kontinyu, artinya sebagai kegiatan dakwah yang senantiasa terus menerus harus dilaksanakan.

Tabligh harus dikembangkan mengikuti lajunya zaman supaya mampu menjabarkan kebenaran, yaitu sesuai dengan kebutuhan dan tuntutan masyarakat sebagai objek dakwah yang patut dipikirkan secara bersama karena amar ma'ruf nahyi munkar. Bentuk-bentuk dakwah terus menerus berkembang, karena itu diperlukan mubaligh atau organisasi dakwah yang tahu bagaimana berbicara aktual serta peka terhadap segala persoalan kongkrit hari ini. Setiap mubaligh atau organisasi dakwah seperti organisasi jamiyah pengajian memiliki ciri-ciri dan penekanan tersendiri serta mempunyai metode serta pola dalam tablighnya.

Dalam penelitian ini, permasalahan yang diangkat adalah mengenai pola tabligh yang terjadi dalam organisasi jamiyah Nurul Iman Kota Bandung. Dalam realitas, tidak banyak organisasi atau perkumpulan dari para pedagang yang mengadakan kegiatan-kegaiatan keagamaan. Peneliti menggunakan metode penelitian deskriptif dengan menggunakan pendekatan kualitatif. Yaitu dengan mengumpulkan data, baik dari hasil observasi atau wawancara. Kemudian memaparkan segala sesuatu yang terjadi di lokasi penelitian dengan berdasarkan kepada data yang diperoleh dan ditunjang dengan tinjauan pustaka yang sesuai dengan permasalahan yang sedang diteliti.

Maka dari itu peneliti menggunakan teori yang membahas tentang tabligh dan pola komunikasi. Karena pada dasarkan tabligh dan komunikasi tidak jauh berbeda dalam pelaksanaannya. Selain itu penelitian ini ditunjang dengan teori komunikasi persuasi dan komunikasi efektif.

\section{LANDASAN TEORITIS}

Dalam kamus umum Bahasa Indonesia Tabligh diartikan penyiaran ajaran agama Islam. Kata tabligh berasal dari kata Ballagha, Yuballigbu, tablighan yang berarti menyampaaikan, penyampaian, yakni mengajarkan ajaran Allah dan Rasul-Nya kepada orang lain. Tabligh artinya menyampaikan ajaran Allah dan Rasul kepada orang lain yang penyajiannya menurut apa 
adanya (objektif) tanpa adanya unsur paksaan untuk diikuti (Amin, 2009:8). Sedangkan pendapat yang lain dikemukakan oleh Louis Ma'luf sebagaimana hal itu yang dikutip oleh Ahmad Subandi menyatakan bahwa keberadaan lafaz tabligh itu adalah isim masdar yang berarti "menyampaikan", yaitu sampainya satu hal kepada tujuanya atau maksudnya (Sukayat, 2008:2).

Selanjutnya tabligh menurut istilah, Abu Bakar Atjeh berpendapat kalimat tabligh makna yang terkandung sama dengan kalimat dakwah, namun yang jadi benang pemisahnya adalah tabligh mempunyai makna yang lebih sempit daripada dakwah, yaitu menyampaikan apa yang diperintahkan oleh Allah SWT dan rosulnya atau amar ma'ruf nabyi munkar dengan cara lisan maupun tulisan. Untuk lebih jelasnya menurut Ibrahim Imam, tabligh adalah memberikan informasi yang benar, berita yang faktual dan benar adanya, yang bisa membantu manusia untuk membangun keyakinan yang tepat dalam satu kejadian atau dari rangkaian permasalahan. Dalam konteks agama Islam, sebagaimana yang di kemukakan oleh Ahmad Subandi tabligh merupakan sebuah proses kegitan menyampaikan dan memberi informasi mengenai ajaran Islam kepada umat manusia, sampai yang menyampaikan informasi itu (mubaligh) gugur kewajibanya, sedangkan pihak yang menerima (muballagh) menjadi terikat dengan apa yang disampaikan (maudu at-Tabligh).

Tujuan tabligh sama halnya dengan tujuan dakwah, tabligh juga mempunyai satu tujuan yang tidak jauh berbeda, tujuan utamanya adalah nilai atau hasil yang ingin dicapai atau diperoleh dari sebuah kegiatan tabligh. Oleh karena itu Sukriyadi Sambas menjelaskan tujuan dakwah Islam dengan mengacu kepada Al-Qur'an sebagai kitab dakwah diantaranta mengeluarkan manusia dari kegelapan hidup (dhulumat) kepada kehidupan terang benderang (nur), menegakan sibghah Allah (celupan hidup dari Allah) dalam kehidupan makhluk Allah, menegakkan fitrah insaniyah, memproporsikan tugas ibadah manusia sebagai makhluk Allah, mengestafetkat tugas kenabian dan kerasulan, memenangkan tugas ilham taqwa mengalahkan ilham fuzur (Enjang, 2009:101).

Selain itu, terdapat pula unsur-unsur yang terkadung dalam kegiatan tabligh. Pada garis besarnya unsur-unsur tabligh tidak jauh berbeda dengan unsur komunikasi yaitu pelaku (komunikator), objek (komunikan), pesan (message), metode, dan media.

Pada dasarnya materi tabligh tidak jauh berbeda dengan materimateri atau pesan-pesan dakwah Islam. Karena tabligh merupakan 


\section{Y. H. Permana \& Z. Abidin}

pengerucutan dari kegiatan dakwah Islam. Maka dari itu, materi yang terkandung dalam kegiatan tabligh juga berisikan ajaran keislaman. Dalam setiap kegiatan tabligh seorang muballigh merealisasikan pemahaman keislaman kepada muballagh yang bersumber dari Al-Qur'an dan AlHadits. Secara konseptual pada dasarnya materi dakwah Islam tergantung pada tujuan dakwah yang hendak dicapai. Namun, secara global materi dakwah dapat diklasifikasikan menjadi tiga pokok, yaitu masalah keimanan, masalah keislaman, dan masalah budi pekerti (Amin, 2009:89).

Disamping itu, materi dakwah yang bersifat terhadap masalahmasalah yang dihadapi dalam kehidupan sosial kemasyarakatan pada umumnya, menurut Barnawi Umari dalam bukunya Samsul Munir Amin (2009:92) materi dakwah Islam antara lain seperti aqidah, akhlak, ahkam, ukhuwah, pendidikan, sosial, kebudayaan, kemasyarakatan, dana mar ma'ruf nahi munkar.

Pola tabligh meliputi dua kata yaitu pola dan tabligh, dalam kamus ilmiah populer dijelaskan bentuk atau model (atau lebih abstrak suatu set peraturan) yang dipakai untuk membuat atau menghasilkan sesuatu atau bagian dari sesuatu dengan maksud bisa mendapatkan dasar yang sejenis untuk bisa sama atau dikembangkan.

Perspektif ilmu komunikasi memandang mengenai model atau pola ini adalah representasi dari sebuah fenomena tertentu dengan menonjolkan unsur-unsur dari fenomena tersebut. Model tersebut menurut Gordon Wiseman Lary Barker mempunyai tiga fungsi yang utama, yang pertama adalah untuk melukiskan sebuah proses kumunikasi, kedua untuk menunjukan hubungan visual, dan ketiga untuk membantu dan memperbaiki kemacetan dalam berkomunikasi sehingga tersampaikanya pesan dengan baik (Mulyana, 2001:123).

Menurut Sereno dan Mortesen model komunikasi merupakan deskripsi ideal mengenai apa yang dibutuhkan untuk terjadinya komunikasi, sedangakan B Aubrey Fisher mengatakan bahwa model adalah analogi yang mengabstaksikan dan memilih bagian dari keseluruhan unsur, sifat atau komponen terpenting dari fenomena yang dijadikan model. Model adalah gambar informal untuk menjelaskan atau menerapakan teori dengan kata lain model adalah teori yang disederhanakan. Atau seperti yang dikatakan Werner J Severin dan James W. Tankard, Jr model membantu merumuskan teori dan menyarankan hubungan. Kita dapat menggunakan kata-kata, angka, simbol dan gambar untuk melukiskan model suatu objek teori atau proses (Mulyana, 2013:132). 
Ada beberapa sumber ilmu yang dijadikan ilmu bantu dalam kajian ilmu dakwah diantaranya ilmu komunikasi, dikarenakan adanya kesamaan tujuan antara keduanya. Oleh sebab itu, untuk mempermudah penelitian ini peneliti juga menggunakan teori komunikasi yang relevan dengan objek penelitianya. Diantaranya menurut Hovland, Janis dan Kelley bahwa komunikasi cenderung pada suatu proses, yakni proses pengalihan stimulus pada orang lain dengan tendensi adanya perubahan tingkah laku (to modify the behavior of other individuals) sebagai responnya (Amin, 2009:145).

Sedangkan yang dimaksud dengan tabligh adalah menyampaikan pesan ilahi atau ajaran Islam kepada umat yang berisikan amar ma'ruf nahi munkar agar dipahami dan diimani serta dijadikan pedoman (Muhyiddin, 2002:60) . Maka melihat kontek diatas bisa disimpulkan bahwa pola tabligh adalah rangcangan model dasar untuk merumuskan sebuah kegiatan tabligh agar tersampaikan dengan baik kepada umat sesuai dengan konteks dan tujuanya.

Melihat rujukan di atas bahwa ketika kita membicarakan pola, sama halnya dengan contoh ataupun model maka dapat dipahami pula secara teoritis bahwa pola tabligh adalah contoh, model atau ragam yang digunakan oleh juru dakwah untuk mempengaruhi mad'unya melalui komunikasi yang terarah dengan maksud tersampaikanya tujuan tertentu.

Pola tabligh yang baik akan membantu mencapai keberhasilan dalam suatu proses tabligh di tengah-tengah umat. Karena hal ini sangat berperan penting terhadap tabligh yang disampaikan, dengan adanya sebuah pola jelas seorang juru dakwah dalam hal ini mubaligh akan memiliki sebuah konsepan tabligh meliputi persiapan pra tabligh, proses berlangsungnya tabligh, bahkan sampai pada memahami objek tabligh yang akan jadi sasarannya.

Tabligh dapat diartikan dari dua sudut pandang yakni pembinaan dan pengembangan. Tabligh yang bersifat pembinaan adalah suatu usaha untuk mempertahankan, melestarikan dan menyempurnakan umat manusia agar tetap beriman kepada Allah SWT. Sedangkan, tabligh yang bersifat pengembangan yakni usaha untuk mengajak manusia yang belum pernah beriman kepada Allah SWT, agar memeluk agama Islam (Syukir, 1983:20).

Salah satu cara tabligh adalah khitobah atau ceramah, yakni suatu tekhnik atau metode tabligh yang banyak diwarnai karakteristik bicara penceramah atau muballigh pada aktivitas tabligh (Asmuni Syukir, 1983:104). Dalam metode khitobah, dipelajari metode kerja, penggunaan alat-alat yang dipakai dalam kerja tersebut. 


\section{Y. H. Permana \& Z. Abidin}

Kegiatan tabligh juga membutuhkan organisasi. Organisasi adalah perkumpulan atau wadah bagi sekelompok orang untuk bekerjasama, terkendali dan terpimpin untuk tujuan tertentu (Fatoni, 2008). Menurut para ahli terdapat beberapa pengertian organisasi sebagai berikut:

Schien (1982) mengatakan bahwa organisasi adalah suatu koordinasi rasional kegiatan sejumlah orang untuk mencapai beberapa tujuan umum melalui pembagian pekerjaan dan fungsi melalui hierarki otoritas dan tanggung jawab. Schien juga mengatakan bahwa organisasi mempunyai karakteristik tertentu yaitu mempunyai struktur, tujuan, saling berhubungan satu bagian dengan bagian lain dan tergantung pada komunikasi manusia untuk mengkoordinasikan aktivitas dalam organisasi tersebut.

Kochler (1976) mengatakan bahwa organisasi adalah sistem hubungan terstruktur yang mengkoordinasikan usaha suatu kelompok orang untuk mencapai tujuan tertentu. Lain lagi dengan pendapat Wright (1977); dia mengatakan bahwa organisasi adalah suatu bentuk sistem terbuka dari aktivitas yang dikoordinasikan oleh dua orang atau lebih untuk mencapai suatu tujuan bersama.

Walaupun ketiga pendapat tentang organisasi terlihat berbeda-beda perumusannya namun ada tiga hal yang sama-sama dikemukakan yaitu: organisasi merupakan sistem, mengkoordinasikan aktivitas dan mencapai tujuan bersama atau tujuan umum. Dikatakan organisasi merupakan sistem karena organisasi terdiri dari beberapa bagian yang saling tergantung satu sama lain. Bila satu bagian terganggu maka akan mengganggu bagian lain.

Organisasi dakwah yaitu usaha dan gerakan dakwah yang dilakukan oleh orang banyak dan mempunyai susunan yang teratur untuk mencapai tujuan dengan cara yang baik dan tepat. Secara umum organisasi dakwah atau institusi Islam di Indonesia dapat dikelompokkan ke dalam dua bagian besar, yaitu organisasi formal dan organisasi informal (Amin, 2009:133).

Organisasi formal ialah sebuah organisasi yang strukturasinya, eksistensi formal atau statusnya diakui baik oleh kalangan luar maupun kalangan dalam. Di kelompok organisasi formal ini, berdasarkan kegiatan utama dan himpunan anggotanya dapat dikelompokkan lagi menjadi yang berciri vertikal atau horizontal, integral atau sektoral.

Organisasi nonformal ialah organisasi atau ikatan jama'ah yang mempunyai ciri-ciri: (1) ikatan anggota dengan organisasi bersifat tidak formal. Ikatan ini hanya karena ide atau kegiatan saja, (2) kepemimpinannya 
bersifat fungsional, (3) jama'ahnya bersifat terbuka, heterogen dan nonafiliatif. Organisasi nonformal mempunyai ciri sektoral atau

Komunikasi, atau dalam bahasa Inggris communication berasal dari kata Latin communicatio, dan bersumber dari kata communis yang berarti sama. Sama di sini maksudnya adalah sama makna (Effendy, 1990:9). Dalam definisinya secara khusus mengenai komunikasi itu sendiri menurut Hovland, Janis dan Kelley adalah "communication is the process by which an individual transmits stimuly (usually verbal) to modify the behaviour of the individuals". Dengan kata lain komunikasi adalah proses individu mengirim stimulus yang biasanya dalam bentuk verbal untuk mengubah tingkah laku orang lain. Pada definisi ini mereka menganggap komunikasi sebagai suatu proses, bukan sebagai suatu hal (Muhammad, 2011:2).

Istilah proses maksudnya bahwa komunikasi itu berlangsung melalui tahap-tahap tertentu secara terus-menerus, berubah-ubah, dan tidak ada henti-hentinya. Proses komunikasi merupakan proses yang timbal balik karena pengirim pesan dan penerima pesan saling mempengaruhi satu sama lain (Muhammad, 2011:5).

Dalam suatu interaksi antarindividu, seperti halnya kegiatan tabligh di majelis taklim, pertemuan di tempat kerja, ataupun belajar-mengajar di sekolah, komunikasi sendiri bertujuan menghidupkan suasana interaksi yang berlangsung sehingga diperoleh efek yang maksimal, baik efek kognitif, afektif, maupun psikomotorik (Muhtadi, 2012:15).

Tujuan dari komunikasi adalah mengharapkan adanya partisipasi dari komunikan atas ide-ide atau pesan-pesan yang disampaikan oleh pihak komunikator sehingga dari pesan yang disampaikan tersebut terjadi perubahan sikap dan tingkah laku yang diharapkan (Amin, 2009:145). H.A.W. Widjaja menyebutkan dalam bukunya, pada umumnya komunikasi dapat mempunyai beberapa tujuan antara lain:

Pertama, supaya yang kita sampaikan itu dapat dimengerti. Sebagai komunikator kita harus menjelaskan kepada komunikan (penerima) dengan sebaik-baiknya dan tuntas sehingga mereka dapat mengikuti apa yang kita maksudkan.

Kedua, memahami orang lain. Kita sebagai pimpinan atau komunikator harus memahami benar aspirasi masyarakat atau komunikan tentang apa yang diinginkannya, jangan mengininkan arah untuk pergi ke Barat tetapi kita memberikan jalan pergi ke Timur. 


\section{Y. H. Permana \& Z. Abidin}

Ketiga, supaya gagasan kita dapat diterima oleh orang lain. Kita harus berusaha agar gagasan kita dapat diterima oleh orang lain dengan pendekatan yang persuasif bukan memaksakan kehendak.

Keempat, menggerakkan orang lain untuk melakukan sesuatu. Menggerakkan sesuatu itu dapat bermacam-macam, mungkin berupa kegiatan. Kegiatan yang dimaksud disini adalah kegiatan yang lebih banyak mendorong, namun yang penting harus diingat adalah bagaimana cara yang baik untuk melakukannya.

Pola komunikasi seorang da'i disesuaikan dengan anggota dan komunikan pada saat berinteraksi. Pembentukan pola komunikasi dipengaruhi oleh beberapa faktor yaitu sejarah atau pengalaman masa lalu yang membentuk kebiasaan, kapasitas diri sebagai akibat dari faktor pendidikan, pelatihan serta pengalaman hidup, maksud dan tujuan dari aktivitas komunikasi (Ma'arif, 2010:79).

Untuk kepentingan retorika, seorang pembicara (komunikator) dapat menggunakan 4 (empat) pola komunikasi, yakni berbicara langsung apa yang dipikirkan (impromtu remark), membaca naskah (reading from manuscript), menghafal (memorizing the speech), memaparkan dengan menggunakan catatan garis besarnya (delivering extemporaneously) (Hybels and Weaver II, 1992:339, dan Rakhmat, 1993:6-8).

Dalam komunikasi terdapat beberapa aspek, diantaranya persuasi dan efektif. Istilah persuasi bersumber dari bahasa latin, yaitu persuasio yang berarti membujuk, mengajak atau merayu. Persuasi merupakan usaha untuk mengubah sikap melalui penggunaan pesan, berfokus terutama pada karakteristik komunikator dan komunikan. Sehingga komunikasi persuasi lebih jelasnya merupakan komunikasi yang berusaha untuk mengubah sikap komunikan melalui penggunaan pesan yang dilakukan komunikator.

K. Andeerson menyatakan komunikasi persuasif didefinisikan sebagai perilaku komunikasi yang mempunyai tujuan mengubah keyakinan, sikap atau perilaku individu atau kelompok lain melalui transmisi beberapa pesan. Menurut R. Bostrom komunikasi persuasif adalah perilaku komunikasi yang bertujuan mengubah, memodifikasi atau membentuk respon (sikap atau perilaku) dari penerima pesan. Dalam pengertian yang lebih luas, persuasif dapat diartikan sebagai suatu proses mempengaruhi pendapat, dan tindakan orang dengan menggunakan manipulasi psikologi, sehingga orang tersebut bertindak atas kehendaknya sendiri (Ilaihi, 2010:125). 
Disamping itu, ada pula komunikasi efektif. Berkomunikasi efektif berarti bahwa komunikator dan komunikan sama-sama memiliki pengertian yang sama tentang suatu pesan. Oleh karena itu, dalam bahasa asing orang menyebutkan "the communication is in tune", yaitu kedua belah pihak yang berkomunikasi sama-sama mengerti apa pesan yang disampaikan. Wahyu Ilaihi mengemukakan dalam buku Komunikasi Dakwah (2010:157), menurut Steward L Tubbs komunikasi dapat dikatakan efektif apabila ditandai dengan adanya pengertian, dapat menimbulkan kesenangan, mempengaruhi sikap, meningkatkan hubungan sosial yang baik, dan pada akhirnya menimbulkan suatu tindakan.

\section{HASIL DAN PEMBAHASAN}

Pada tahun 2000 beberapa orang yang berprofesi sebagai pedagang nasi goreng asal Kota Tegal Jawa Tengah ingin mendirikan sebuah perkumpulan antar sesama pedagang nasi goreng. Mereka diantaranya Solikhin, Zamroni, Mu'in, Dasuki, Hermanto, Aripin dan Tarjono. Mereka berangan-angan ingin mengadakan paguyuban atau perkumpulan sesama pedagang nasi goreng khususnya yang berasal dari Jawa Tengah yang tinggal di Kota Bandung. Namun tidak hanya perkumpulan atau paguyuban biasa, Solikhin khususnya menginginkan perkumpulan yang akan dibangun tersebut tidak lepas dari kegiatan-kegiatan keagamaan.

Disamping itu, Solikhin juga tidak menginginkan rekan-rekannya terjerumus dengan kegitan yang tidak bermanfaat seperti berjudi dan menghambur-hamburkan waktu dan uang dengan hal-hal yang tidak bermanfaat. Seperti perkataannya pada wawancara yang dilakukan peneliti kepada ketua jamiyah Nurul Iman.

Setelah berjalan selama beberapa tahun, pada tahun 2007 perkumpulan ini hampir mengalami pembubaran, menurut informasi yang peneliti dapat dari wawancara dengan ketua jamiyah Nurul Iman, hal ini dikarenakan kurang antusias dari para anggota dan jama'ah dalam melaksanakan kegiatan serta faktor waktu dan keuangan. Keadaan ini berangsur selama 3 tahun. Dalam masa pasang surutnya perkumpulan jamiyah Nurul Iman, Bapak Solikhin lebih giat dalam mengajak rekanrekannya untuk mengikuti perkumpulan jamiyah Nurul Iman dengan dibantu oleh rekan seperjuangannya dalam mendirikan organisasi jamiyah Nurul Iman. 


\section{Y. H. Permana \& Z. Abidin}

Ada salah seorang teman dari Bapak Sholikhin yang bernama Agung Wibowo mengikuti perkumpulan jamiyah Nurul Iman. Beliau bekerja sebagai pegawai pajak di Jl. Cianjur No 1 Bandung. Dengan pengalamannya sebagai seorang yang aktif berkecimpung di organisasi, akhirnya beliau banyak memberikan masukan serta arahan kepada ketua jamiyah Nurul Iman untuk menjadikan jamiyah Nurul Iman bukan hanya sebagai perkumpulan biasa saja, namun lebih diperjelas dan lebih diseriuskan dalam sistem administrasinya.

Sejak tahun 2010 jamiyah Nurul Iman mulai mengalami kebangkitan kembali dan semakin berkembang dengan bertambahnya jumlah anggota atau jama'ah serta semakin erat hubungan antar pengurus dengan anggota. Hal ini tidak telepas dari tujuan awal untuk mengurangi kegiatan negatif yang biasa dilakukan oleh para anggota sebelum masuk dalam organisasi ini.

Jamiyah Nurul Iman Kota Bandung memiliki visi mempererat tali silaturahmi antar pedagang di perantauan, berakhlakul karimah, amar ma'ruf nahyi munkar. Dan misi jamiyah Nurul Iman adalah mengajak dan mempersatukan saudara satu perantauan dalam sebuah perkumpulan keagamaan, melakukan syiar agama dalam setiap kegiatan, membantu sesama anggota dalam pemfasilitasan dana usaha.

Sejak berdirinya jamiyah Nurul Iman sampai dengan sekarang, Bapak Solikhin menjabat sebagai ketua. Untuk membantu kinerja ketua perlu adanya pihak lain seperti pembina yang dipegang oleh Agung Wibowo. Sekretaris jamiyah Nurul Iman Kota Bandung ada 2 orang, yaitu Zamroni dan Iwan. Bendahara dipercayakan kepada H. Wiryono. Kemudian terdapat seksi-seksi, seperti seksi agama yang dipegang oleh Ustad Toha dan H. Entang, humas oleh Tarjono dan Saroni, seksi acara oleh Ustad Toha, logistik oleh Dasuki dan Rudin, seksi konsumsi oleh Hermanto dan Arifin, serta seksi keamanan oleh Pardi dan Slamet.

Berdasarkan data keanggotaan jamiyah Nurul Iman Kota Bandung, jumlah anggota jamiyah Nurul Iman Kota Bandung sampai dengan bulan Juli 2016 ada 57 orang, jumlah tersebut termasuk pengurus serta anggota jamiyah Nurul Iman Kota Bandung. Berdasarkan profesi, jumlah anggota jamiyah Nurul Iman Kota Bandung, yaitu pedagang nasi goreng berjumlah 40 orang, tukang onde berjumlah 1 orang, tukang kios berjumlah 1 orang, tukang bakso berjumlah 4 orang, penjual sembako berjumlah 1 orang, tukang martabak berjumlah 1 orang, penjual perabot rumah tangga berjumlah 1 orang, warteg atau warung makan berjumlah 3 orang, 
photografer berjumlah 1 orang, wirausaha berjumlah 1 orang, PNS berjumlah 1 orang, pensiunan PNS berjumlah 1 orang dan seorang TNI berjumlah 1 orang.

\section{Program Kegiatan Organisasi Jamiyah Nurul Iman}

Dalam sebuah organisasi sudah menjadi kewajiban harus adanya sebuah kegiatan yang menjadi aktivitas dari organisasi tersebut. Organisasi jamiyah Nurul Iman selalu melakukan kegiatan-kegaitan keagamaan. Program kegiatan jamiyah Nurul Iman Kota Bandung diantaranya pengajian rutin bulanan, simpan pinjam dana usaha, halal bi halal, bakti sosial.

Pertama, pengajian merupakan kegiatan berkumpulnya orang-orang muslim dalam sebuah forum atau majelis untuk membaca dan mengkaji ayat-ayat suci Al-Qur'an dan membacakan tahlil serta mempelajari ajaran Islam. Dalam pengajian ini terdapat tabligh atau ceramah yang disampaikan oleh seorang tokoh ulama (mubaligh) setelah membacakan ayat-ayat suci Al-Qur'an dan tahlil. Pengajian rutinan ini dilaksanakan satu bulan sekali pada setiap malam Jum'at. Adapun tempat pelaksanaan pengajian rutin bulanan jamiyah Nurul Iman tidak hanya di satu tempat saja, tetapi bergilir di tempat anggota jamiyah Nurul Iman sesuai dengan kesepakatan pengurus dan anggota jamiyah Nurul Iman.

Pengajian rutin yang diselenggarakan jamiyah Nurul Iman dijadikan sebagai momentum untuk mendalami ajaran agama Islam. Dimana dalam kegiatan tersebut pengurus serta anggota atau jama'ah saling belajar tentang ilmu agama Islam yang dibimbing langsung oleh seorang juru dakwah. Menurut ketua jamiyah Nurul Iman, karena mayoritas anggota jamiyah Nurul Iman adalah pedagang, maka tingkat pemahaman agamanya tidak terlalu tinggi. Dengan adanya kegiatan keagamaan di jamiyah Nurul Iman dapat memberikan pemahaman terkait ilmu agama Islam kepada seluruh anggota jamiyah Nurul Iman serta sebagai evaluasi diri untuk berubah menjadi manusia yang lebih baik dalam kehidupan bermasyarakat.

Tausiah pada pengajian rutin yang diselenggarakan oleh jamiyah Nurul Iman disampaikan oleh Ustad Toha, dimana beliau adalah pengurus sekaligus anggota jamiyah Nurul Iman Kota Bandung. Disamping sebagai pedagang nasi goreng, beliau juga dikenal sebagai imam masjid di daerahnya serta terkadang diminta untuk ceramah ketika ada kegiatan keagamaan di lingkungan beliau tinggal. Selain Ustad Toha, H. Entang juga mendapatkan tugas untuk mengisi tausiah. Beliau merupakan sepuh di jamiyah Nurul Iman Kota Bandung. Menurut informasi yang peneliti 


\section{Y. H. Permana \& Z. Abidin}

dapatkan dari hasil wawancara, dalam kehidupan sehari-hari H. Entang selalu mendapatkan penggilan untuk mengisi ceramah di daerah lain.

Terkadang jamiyah Nurul Iman juga mengundang seorang da'i atau ustad diluar anggota jamiyah Nurul Iman. Hal ini dilakukan untuk membuat suasana sedikit berbeda dari biasanya. Dengan adanya da'i yang di undang dari luar anggota jamiyah Nurul Iman, bertambah pula pengalaman serta dijadikan sebagai referensi dalam melakukan tabligh bagi da'i dalam anggota jamiyah Nurul Iman di masa yang akan datang. Pengajian rutin bulanan hanya berlangsung sepuluh kali dalam satu tahun. Pada saat bulan ramadhan pengajian rutin diliburkan dan satu bulan lebih setelah hari raya Idul Fitri juga masih libur.

Kedua, salah satu tujuan dibentuknya jamiyah Nurul Iman adalah untuk menfasilitasi barang dagangan atau dana usaha dengan sistem pinjaman melalui uang kas anggota jamiyah Nurul Iman. Karena mayoritas anggota jamiyah Nurul Iman berprofesi sebagai pedagang atau wiraswasta, maka simpan pinjam dana usaha dianggap sangat membantu dalam meringankan beban apabila anggota sedang mengalami kekurangan modal dalam usaha. Pemberian pinjaman kepada semua anggota jamiyah Nurul Iman dilakukan pada saat pertemuan terakhir pengajian rutinan sebelum menginjak bulan ramadhan. Jadi, pada saat bulan ramadhan, jamiyah Nurul Iman tidak melakukan pengajian rutin bulanan seperti biasa dan satu bulan lebih selesai hari raya Idul Fitri.

Selain sebagai agenda kegiatan organisasi, simpan pinjam dana usaha bertujuan untuk membantu sesama anggota, menjaga tali silaturahim antar pengurus dan anggota, serta merupakan sebuah cara yang dilakukan untuk mendekatkan diri dengan anggota jamiyah Nurul Iman untuk tetap mengikuti jamiyah Nurul Iman.

Ketiga, halal memiliki makna mengikhlaskan. Dengan kata lain halal bi halal dapat diartikan sebagai ungkapan untuk saling mengikhlaskan atau saling maafkan satu sama lain. Halal bi halal merupakan tradisi bersilaturahim dan saling memaafkan kepada setiap muslim setelah melaksanakan ibadah puasa pada bulan Ramadhan satu bulan lamanya. Sudah sepatutnya sebagai manusia yang mempunyai banyak dosa dan salah saling memaafkan satu sama lain. Datangnya hari raya Idul Fitri merupakan waktu yang tepat untuk mensucikan diri dari segala dosa antar sesama umat manusia, karena pada hari raya Idul Fitri Allah SWT'T mensucikan semua dosa-dosa hamba-Nya yang sungguh-sungguh mengharapkan ampunan 
dari-Nya. Hal ini sejalan dengan pesan yang dibawa oleh ajaran Islam tentang tindakan saling memaafkan dalam interaksi sesama manusia.

Keempat, bakti sosial dilakukan dengan memberikan bahan-bahan pokok, pakaian, atau pun dapat berupa uang tunai. Setiap satu tahun satu kali jamiyah Nurul Iman melakukan bakti sosial kepada masyarakat yang membutuhkan. Jamiyah Nurul Iman melaksanakan bakti sosial setelah melakukan tabligh akbar di acara halal bi halal. Pelaksanaan bakti sosial dilakukan pada tempat yang berbeda setiap tahun. Karena kegiatan bakti sosial berbarengan dengan kegiatan halal bi halal, maka tempat serta sasaran bakti sosial adalah di tempat pelaksanaan halal bi halal serta masyarakat sekitar.

\section{Pola Materi Tabligh Organisasi Jamiyah Nurul Iman}

Keberhasilan tabligh tidak terlepas dari pesan atau materi yang disampaikan oleh da'i kepada mad'u. Pemilihan materi yang sesuai dengan kondisi mad'u menjadi dasar yang penting sebelum melaksanakan aktivitas tabligh dihadapan jama'ah. Seorang da'i harus pandai melihat kondisi mad'unya. Seiring dengan perkembangan zaman yang membuat kegiatan tabligh yang semakin variatif, da'i dituntut harus mampu menyesuaikan diri dengan keadaan lingkungan dan keadaan mad'unya. Sehingga dalam merumuskan materi tabligh, dapat memilah dan menyortir materi tabligh manakah yang sesuai dan tepat untuk membuat hati para mad'u menerima dan merealisasikan pesan tabligh yang nantinya akan disampaikan. Sebelum merumuskan materi tabligh pun harus mempersiapkan hal-hal yang menjadi pondasi awal dalam merumuskan suatu materi tabligh.

Menyikapi kondisi tersebut, jamiyah Nurul Iman mempersiapkan beberapa hal sebelum meyusun materi pokok tabligh yang nantinya akan dikembangkan dan dirumuskan kembali oleh H. Entang dan Ustad Toha selaku mubaligh yang bertugas menyampaikan ceramah pada kegiatan di jamiyah Nurul Iman. Adapun beberapa hal yang harus diperhatikan dalam penyusunan materi tabligh, yaitu mencari sumber materi tabligh, merumuskan materi tabligh, dan kemudian mengklasifikasikan materi tabligh.

Dalam penyusunan materi tabligh sudah tentu harus memperhatikan sumber materi tabligh. Dari mana materi tabligh yang nantinya akan disusun secara terstruktur. Sumber utama ilmu tentang agama Islam yaitu Al-Qur'an dan Hadits. Al-Qur'an merupakan pedoman hidup seluruh umat manusia yang telah dijamin dan dijaga keasliannya oleh Allah SWT, Hadits 


\section{Y. H. Permana \& Z. Abidin}

merupakan sumber kedua dalam Islam. Hadits merupakan penjelasanpenjelasan dari Nabi dalam merealisasikan kehidupan berdasarkan $\mathrm{Al}-$ Qur'an. Maka, dalam hal ini untuk memperoleh materi tentang agama Islam tinggal mengkaji nilai-nilai yang terkandung dalam Al-Qur'an serta didukung dengan perbuatan atau perkataan Nabi Muhammad SAW.

Selanjutnya yang dilakukan adalah mencari ayat-ayat Al-Qur'an atau informasi yang terkandung dalam Al-Qur'an dan Hadist yang kemudian dirumuskan menjadi beberapa pokok materi. Setelah didapatkan informasi dan dasar hukum dari pokok materi tersebut dilakukanlah pengklasifikasian materi tabligh. Pengklasifikasian memiliki fungsi untuk menempatkan atau menyortir materi-materi yang sejenis atau memiliki kesamaan isi.

Dalam kegiatan pengajian rutin bulanan, pengklasifikasian materi tabligh dapat dibagi dalam beberapa jenis, diantaranya mengenai aqidah, akhlak, ukhuwah, sosial, masyarakat dan amar ma'ruf nahi munkar. Selayaknya sebagai seorang pedagang sekaligus paguyuban pedagang yang merantau di Bandung, maka materi tabligh tersebut dianggap sesuai dalam menyampaikan pesan-pesan ajaran Islam di dalam organisasi tersebut.

Berdasarkan hasil pengamatan yang peneliti dapat melalui observasi langsung, peneliti melihat pada beberapa aktivitas tabligh yang dilakukan oleh mabaligh jamiyah Nurul Iman Kota Bandung yaitu Ustad Toha dan H. Entang dan mendapatkan hasil sebagai berikut:

Pertama, pada pengajian rutin bulanan, Ustad Toha menyampaikan materi tabligh dengan topik tentang ibadah. Ibadah yang disampaikan dalam ceramah tersebut adalah tentang sholat. Setiap muslim diwajibkan untuk melaksanakan sholat.

Ustad Toha menyampaikan materi dengan menggunakan bahasa yang mengajak untuk melaksanakan perintah Allah SWT. Pemilihan materi tersebut berdasarkan atas aktivitas para pedagang yang menggunakan banyak waktunya untuk mencari rezeki. Tidak sedikit dari kebiasaan pedagang yang lalai melaksanakan ibadah seperti sholat. Maka dari itu, materi tersebut dianggap dapat mengingatkan para jama'ah yang mayoritas adalah seorang pedagang untuk lebih meningkatkan ibadah sholat lima waktunya.

Kedua, ceramah yang dilakukan oleh Ustad Toha dengan tema amal shaleh. Amal shaleh yang disebutkan dalam ceramah tersebut tentang silaturahim. Disamping sebagai pesan-pesan keislaman, materi silaturahim disampaikan untuk lebih mempererat rasa kekeluargaan yang dibangun melalui jamiyah Nurul Iman Kota Bandung. 
Ketiga, ceramah yang dilakukan oleh H. Entang dengan tema amar ma'ruf nahi munkar. H. Entang merupakan tokoh agama sekaligus sepuh di jamiyah Nurul Iman. Beliau banyak menyampaikan ajakan-ajakan untuk selalu berbuat baik kepada sesama manusia. Disamping itu, H. Entang selalu mengingatkan kepada para jama'ah untuk menjauhi segala perbuatan buruk yang dahulu ada atau pernah diperbuat. Karena setiap perbuatan yang buruk akan mendatangkan akibat yang buruk pula kepada diri sendiri.

Dari ketiga tema ceramah hasil aktivitas tabligh di atas, peneliti melihat materi tabligh yang disampaikan masih bersifat umum, namun arah dari materi yang disampaikan merupakan hal-hal yang berbentuk amalan dalam perilaku sehari-hari dan berhubungan dengan kehidupan bermasyarakat supaya terbentuk akhla yang baik (akhlakul karimah).

\section{Pola Metode Tabligh Organisasi Jamiyah Nurul Iman}

Pola metode tabligh yang berdasarkan dari komunikasi secara materi dilihat dari mubaligh yang melakukan ceramah, sedangkan secara aksi merupakan pola metode tabligh yang dilihat dari bentuk kegiatan tabligh yang dilakukan organisasi jamiyah Nurul Iman. Pola metode tabligh secara aksi dapat dilihat dari bentuk-bentuk kegiatan tabligh seperti silaturahim, paguyuban dan gotong royong.

Pertama, silaturahim atau menyambungkan tali persaudaraan merupakan amalan yang sangat mulia. Berkaitan dengan keutamaan silaturahim ini, Baginda Rasulullah SAW bersabda: "Barang siapa yang beriman kepada Allah dan hari akhir, hendaknya menyambungkan tali silaturabim". Kemudian hadits yang lain juga mengatakan: "Barang siapa yang suka atau ingin dipanjangkan umurnya dan diluaskan rizkinya, bendaknya menyambungkan tali silaturahim". Tentunya banyak lagi hadits-hadits lain yang mengutarakan pentingnya menjalin tali silaturahim di antara sesama muslim.

Bagi organisasi jamiyah Nurul Iman, silaturahim merupakan salah satu metode dalam melaksanakan kegiatan dakwah. Ada dua cara silaturahim yang dilakukan dalam organisasi jamiyah Nurul Iman. Pertama, dengan cara mendatangi jama'ah atau anggota jamiyah Nurul Iman di setiap pangkalan usahanya. Hal ini dilakukan apabila jama'ah atau anggota sedang mengalami kesulitan atau musibah. Salah seorang atau beberapa orang pengurus jamiyah diutus oleh ketua untuk berkunjung. Kedua, dengan adanya pengajian rutin bulanan. Satiap satu bulan sekali organisasi jamiyah Nurul Iman mengadakan pertemuan rutin dengan seluruh jama'ah atau anggota yaitu dalam kegiatan pengajian. Hal ini merupakan salah satu 


\section{Y. H. Permana \& Z. Abidin}

metode untuk bersilaturahim dengan semua jama'ah, baik itu anggota atau pengurus jamiyah Nurul Iman. Karena tidak mungkin pengurus mendatangi satu persatu jama'ah atau anggota dalam silaturahmi di tempat usaha setiap anggota, maka dengan cara ini semua jajaran pengurus serta jama'ah atau anggota jamiyah Nurul Iman dapat berkumpul dan bersilaturahim.

Selain itu, metode silaturahim diterapkan melalui kegiatan halal bi halal yang dilakukan jamiyah Nurul Iman setiap tahun. Dasar acara halal bi halal dalam jamiyah Nurul Iman adalah menyambung tali silaturahim antar sesama anggota jamiyah Nurul Iman serta masyarakat di lokasi acara halal bi halal.

Kedua, metode paguyuban. Paguyuban dapat dikatakan sebagai persekutuan atau kebersamaan aneka ragam orang, dimana anggotanya diikat oleh hubungan batin yang murni dan bersifat alamiah. Dapat dikatakan demikian karena dasar hubungan antara mereka adalah rasa cinta dan rasa persatuan batin. Hal ini dapat dilihat dari nilai-nilai umum yang terdapat di dalam sebuah paguyuban, yaitu semangat kebersamaan, sehati dan sejiwa dalam suka dan duka untuk melaksanakan tugas, memiliki kepekaan dan bertindak saling kasih mengasihi, bentuk kehidupan bersama yang menghayati solidaritas dan toleransi dalam memaafkan segala perbedaan untuk mencapai tujuan bersama.

Berkaitan dengan hal tersebut, melalui metode paguyuban kegiatan tabligh yang disampaikan dalam sebuah paguyuban berpotensi besar akan menghasilkan efektivitas tabligh yang baik. Maka dari itu jamiyah Nurul Iman mengajak anggota atau jama'ah lain dengan berdasarkan kepada nilainilai yang terkandung dalam paguyuban tersebut. Seperti yang telah peneliti jelaskan, anggota jamiyah Nurul Iman Kota Bandung mayoritas berasal dari Jawa Tengah, terutama dari Kota Tegal yang merantau di Kota Bandung. Disamping itu, mayoritas profesi anggota jamiyah Nurul Iman adalah sebagai pedagang. Sudah dapat dilihat secara jelas pengurus serta anggota jamiyah Nurul Iman memiliki satu perjuangan yang sama. Dengan menggunakan metode paguyuban, jamiyah Nurul Iman merealisasikan aktivitas tabligh dalam kegiatan pengajian rutin dan kegiatan halal bi halal.

Ketiga, metode gotong royong. Dalam kehidupan bermasyarakat, manusia sebagai makhluk sosial tidak dapat hidup tanpa adanya bantuan atau hubungan dari orang lain. Dengan bergotong royong segala pekerjaan atau urusan dapat diselesaikan dengan mudah. Gotong royong berarti bekerja bersama-sama untuk mencapai hasil yang diharapkan. Dalam hal 
ini, gotong royong yang dimaksud adalah bukan membersihkan lingkungan secara bersama-sama atau sejenisnya, namun gotong royong yang dimaksud adalah bekerja bersama-sama membuat acara tabligh seperti halnya dalam acara halal bi halal, mengumpulkan dana untuk digunakan mambantu jama'ah atau orang lain yang sedang mengalami kesulitan. Dengan mengusung nilai gotong royong, rasa kebersamaan serta kekompakan antar sesama manusia akan terbangun.

Salah satu metode tabligh yang dilakukan oleh jamiyah Nurul Iman adalah dengan menerapkan nilai-nilai gotong royong, dimana tabligh yang dilakukan adalah berlandaskan kepada nilai-nilai kebersamaan. Melalui kegiatan yang dilakukan secara bersama-sama, pesan tabligh yang disampaikan mubaligh akan mudah sampai kepada hati muballaghnya. Aplikasi metode gotong royong diterapkan pada jamiyah Nurul Iman pada kegiatan simpan pinjam dana usaha dan bakti sosial.

Simpan pinjam dana usaha mengandalkan bantuan dari semua anggota jamiyah Nurul Iman, dengan adanya uang dari hasil iuran setiap anggota dapat digunakan untuk membantu anggota lain ketika membutuhkan uang yang sifatnya mendadak. Berbarengan dengan kegiatan tersebut seorang mubaligh menanamkan pesan-pesan keislaman kepada semua anggota jamiyah Nurul Iman melalui nasihat-nasihat singkat. Hasilnya dengan menerapkan metode gotong royong yang berbentuk simpan pinjam dana usaha akan membuat anggota saling terbantu dan tersentuh hatinya untuk melaksanakan pesan-pesan yang terus disampaikan mubaligh kepada semua anggota jamiyah Nurul Iman.

Disamping itu, penerapan metode gotong royong dalam tabligh terdapat pula pada kegiatan bakti sosial yang dilakukan oleh jamiyah Nurul Iman. Mulai dari pengumpulan dana sampai dengan pelaksanaan kegiatan dilakukan bersama-sama dengan seluruh anggota jamiyah Nurul Iman. Dengan rasa kebersamaan yang sudah melekat pada hati setiap anggota, penyampaian pesan agama Islam kepada seluruh anggota serta masyarakat dianggap lebih efektif.

Hal ini tentunya tidak terlepas dari komunikasi yang mampu mempengaruhi seluruh anggota jamiyah Nurul Iman serta pendekatan yang disusun secara sistematis untuk mendapatkan hati seluruh jama'ah serta anggota jamiyah Nurul Iman untuk mengaplikasikan pesan-pesan keagamaan yang disampaikan. 


\section{Y. H. Permana \& Z. Abidin}

\section{Pola Komunikasi antara Da'i dan Jama'ah Jamiyah Nurul Iman}

Seperti yang sudah dijelaskan mengenai pola tabligh yang sama kaitannya dengan pola komunikasi, pola tabligh merupakan representasi dari sebuah fenomena tabligh dengan menonjolkan unsur-unsur tabligh tersebut. Pada dasarnya kegitan tabligh merupakan kegitan komunikasi, karena pada proses tabligh unsur yang paling berpengaruh adalah komunikasi, yaitu komunikasi yang dilakukan oleh da'i atau mubaligh kepada mad'u atau yang biasa disebut muballagh. Pola komunikasi memberikan gambaran mengenai tingkah laku dalam suatu sistem karena pola komunikasi menyediakan konteks untuk memahami tingkah laku yang spesifik.

Dalam hal ini yang berperan sebagai da'i dari organisasi jamiyah Nurul Iman yaitu Ustad Toha dan H. Entang. Beliau merupakan seorang da'i sekaligus seorang tokoh ulama dalam jamiyah Nurul Iman. Melalui pidato atau ceramah, mad'u manafsirkan tindakan verbal dan nonverbal dari mubaligh tentang nilai-nilai keagamaan yang terdiri dari nilai sosial dan agama. Tindakan verbal merupakan ucapan atau kata-kata yang diucapkan dan mudah dimengerti, sedangkan tindakan nonverbal mengacu kepada tindakan, raut wajah, pakaian dan situasi lingkungan.

Pola komunikasi yang dilakukan oleh Ustad Toha yaitu delivering extemporaneously dan impromtu remark. Beliau menggabungkan pola komunikasi dakwah delivering extemporaneously dan impromtu remark. Sebelum beliau berdakwah, beliau membuat poin-poin yang berisi garis besar materi yang akan disampaikan. Kemudian pada saat berdakwah, Ustad Toha memaparkan atau menguraikan poin-poin tersebut sesuai dengan apa yang beliau ingat. Pesan-pesan yang disampaikan oleh Ustad Toha bersifat emosional, namun tidak meninggalkan aspek rasional, khususnya dalam dunia usaha atau bisnis.

Komunikasi yang dilakukan Ustad Toha pada dasarnya mengandung unsur-unsur persuasif. Karena pada saat beliau berceramah menggunakan komunikasi yang dapat mempengaruhi jama'ah yang mayoritas adalah perkumpulan orang-orang pedagang dengan menyisipkan motivasimotivasi sukses dalam dunia usaha ditengah-tengah ceramah. Tidak hanya membicarakan mengenai dunia usaha saja, Ustad Toha juga selalu mengingatkan jama'ah untuk selalu menjaga tali silaturahim antar anggota jamiyah Nurul Iman dengan menyampaikan keutamaan-keutamaan silaturahim.

Sementara itu, H. Entang menggunakan pola komunikasi impromtu remark, yaitu berbicara secara langsung apa yang dipikirkan dalam aktivitas 
tablighnya. H. Entang yang di pandang sepuh dalam jamiyah Nurul Iman sering membaca buku-buku tentang akidah, fiqh, tasawuf, dan lain sebagainya. Manurutnya membaca buku merupakan gerbang untuk memperoleh wawasan mengenai ilmu agama Islam. Dengan pengalaman dan jam terbang beliau selama berkecimpung sebagai mubaligh, H. Entang tidak merasa canggung dalam berdakwah. Walaupun materi yang disampaikan dalam berdakwah mengalir sesuai dengan apa yang beliau kehendaki, namun tetap relevan dengan tema pokok yang dibahas.

Komunikasi yang dilakukan oleh H. Entang dalam proses ceramahnya merupakan komunikasi yang bersifat persuasif. Beliau selalu mengajak dan mengingatkan jama'ah untuk selalu meninggalkan perbuatan-perbuatan negatif yang masih terlihat dilakukan oleh para jama'ah, serta mempengaruhi jama'ah dengan menggunakan perkataan yang dapat menyentuh hati untuk selalu mengajak sesama manusia melakukan perbuatan-perbuatan yang diridhai Allah SWT.

Untuk mencapai tujuan tabligh yang diharapkan dalam proses penyampaian pesan-pesan tabligh, mubaligh melakukan pendekatanpendekatan dengan jama'ah (Saepuloh, 2009). Dalam proses komunikasi dengan jama'ah, mubaligh melakukan interaksi langsung dengan jama'ah. Menurut pengamatan yang dilakukan peneliti, baik itu Ustad Toha atau H. Entang kerap kali mengajak ngobrol atau berdialog dengan jama'ah. Hal ini dilakukan diluar kegiatan ceramah.

Dari hasil wawancara dengan Ustad Toha, beliau menyebutkan hal demikian dilakukan untuk membangun komunikasi yang baik dengan jama'ah. Dengan saling bercakap-cakap tentunya akan menimbulkan pendekatan dengan jama'ah. Maka dengan demikian sedikit hal yang ada dalam diri jama'ah akan diketahui oleh Ustad Toha selaku mubaligh. Menurutnya ini merupakan komunikasi untuk mendekatkan diri dengan jama'ah supaya beliau dapat mengetahui bagaimana tindakan yang akan dilakukan pada saat menyampaikan pesan-pesan tabligh.

\section{PENUTUP}

Organisasi jamiyah Nurul Iman Kota Bandung memiliki program kegiatan khususnya kegiatan dalam bidang keagamaan seperti pengajian rutin bulanan, simpan pinjam dana usaha, halal bi halal, dan bakti sosial. Sebelum menentukan materi tabligh yang akan disampaikan oleh mubaligh dalam jamiyah Nurul Iman, pengurus mengklasifikasikan materi tabligh yang 


\section{Y. H. Permana \& Z. Abidin}

sesuai dengan kondisi jama'ahnya. Klasifikasi materi tabligh diantaranya adalah tentang aqidah, akhlak, ukhuwah, sosial, masyarakat dan amar ma'ruf nahi munkar. Setelah pengklasifikasian selesai disusun, maka akan dikembangkan oleh Ustad Toha dan H. Entang selaku mubaligh di jamiyah Nurul Iman Kota Bandung. Pada realisasi kegiatan tablighnya mubaligh banyak mengajak jama'ah untuk memperbaiki diri ke arah yang lebih baik. Seperti pada ceramah dengan topik ibadah, amal shaleh dan amar ma'ruf nahi munkar. Dalam beberapa topik ceramah di atas, mubaligh banyak menggunakan kata-kata yang mengajak jama'ah untuk melaksanakan apa yang disampaikan oleh mubaligh serta menggunakan bahasa yang dianggapnya sehati dengan para jama'ah. Hal ini sesuai dengan komunikasi persiasif dan efektif yang dilakukan oleh mubaligh dalam melaksanakan aktivitas tablighnya, yaitu untuk mempengaruhi perbuatan dan tingkah laku jama'ah ke arah yang lebih baik. Pola metode tabligh organisasi jamiyah Nurul Iman Kota Bandung diantaranya metode silaturahim, metode paguyuban dan metode gotong royong. Pola komunikasi yang dilakukan oleh Ustad Toha yaitu delivering extemporaneously (memaparkan dengan menggunakan catatan garis besarnya) dan impromtu remark (berbicara langsung apa yang dipikirkan). Sedangkan H. Entang menggunakan pola komunikasi impromtu remark (berbicara langsung apa yang dipikirkan). Selain itu komunikasi yang dilakukan oleh Ustad Toha dan H. Entang kepada jama'ah Nurul Iman menggunakan komunikasi persuasif, yaitu dengan mempengaruhi para jama'ah dengan tujuan untuk merubah tingkah laku jama'ah kearah yang lebih baik dalam kehidupan beragama dan bermasyarakat.

Setelah melakukan penelitian, peneliti melihat dan merasakan sendiri beberapa kegiatan jamiyah Nurul Iman. Dalam prakteknya kegiatan keagamaan yang dilaksanakan sudah termasuk dalam kategori baik. Banyak nilai-nilai yang terkandung dari setiap kegiatan yang dilaksanakan. Namun alangkah lebih baiknya kegiatan-kegiatan keagamaan jamiyah Nurul Iman Kota Bandung lebih ditingkatkan, serta dalam sistem administratif seperti surat menyurat, daftar hadir dan lain sebagainya lebih di tata kembali. Untuk lembaga akademisi, diharapkanya adanya temuan teori-teori baru yang mampu membantu pandangan para akademisi dalam meneliti kajiankajian tabligh yang semakin hari semakin komplek dan unik. Dengan adanya teori-teori yang baru akan lebih memudahkan para akademisi dalam menyelesaikan tugas yang berhubungan dengan teori dalam penelitian ini. 
Bagi peneliti yang akan datang dan akan meneliti kembali mengenai organisasi jamiyah Nurul Iman Kota Bandung, diharapkan mampu menutupi kekurangan dan menambahkan hal yang baru dari skripsi ini.

\section{DAFTAR PUSTAKA}

Amin, S. M. (2009). Ilmu Dakwah. Jakarta: Amzah.

Enjang AS., \& Aliyudin. (2009). Dasar-Dasar Ilmu Dakwah. Bandung: Widya Padjajaran.

Effendy, O. U. (1990). Ilmu Komunikasi Teori dan Praktik. Bandung: PT. Rosda Karya.

Fatoni, U (2008). Membangun Kredbilitas Mubaligh, Meraih Kepercayaan Jamaah Menuju Keberhasilan Tabligh. ANIDA 8 (1) 1-12.

Ilaihi, W. (2010. Komunikasi Dakwah. Bandung: PT Remaja Rosdakarya.

Kusnawan, A. (2004). Ilmu Dakwah, Kajian Berbagai Aspek. Bandung: Pustaka Bani Qurasy.

Ma'arif, B. S.. (2010). Komunikasi Dakwah Paradigma untuk. Aksi. Bandung: Simbiosa Rekatama.

Muhyiddin, A. (2002). Methode Pengembangan Dakwah. Bandung: Pustaka Setia.

Mulyana, D. (2001). Nuansa-Nuansa Komunikasi. Bandung: PT. Remaja Rosdakarya.

Mulyana, D. (2013). Ilmu Komunikasi. Bandung: PT. Remaja Rosdakarya.

Saepuloh, U. (2009). Model Komunikasi Dakwah Jamaah Tabligh. Ilmu Dakwah: Academic Journal for Homiletic Studies 4 (14) 657-688.

Sukayat, T. (2008). Nasehat Mancar Dina Mimbar. Bandung: Kaisar.

Syukir, A. (1983). Dasar-Dasar Strategi Tabligh. Surabaya: Al-Ikhlas. 